\title{
Instructors' Evaluation as an Instrument to Improve Performance and Determine Competence
}

\author{
Soosan Laei ${ }^{1{ }^{1 *}}$, Ali Abdi ${ }^{2}$, Mohamad Javad Karamaerouz ${ }^{3}$, Nassim Shirkhani ${ }^{4}$ \\ ${ }^{1}$ Department of Educational Sciences, Kermanshah Branch, Islamic Azad University, Kermanshah, Iran \\ ${ }^{2}$ Payam Noor University professor and faculty of the Department of Educational Sciences \\ ${ }^{3}$ Department of Educational Sciences, Kermanshah Branch, Islamic Azad University, Kermanshah, Iran \\ ${ }^{4}$ Department of industries - industries, Science and Research Branch, Islamic Azad University, Arack, Iran \\ *Corresponding Author: s_laei@yahoo.com
}

Copyright (C) 2014 Horizon Research Publishing All rights reserved.

\begin{abstract}
Experts in human resources management have suggested common objectives for evaluating performance of all organizations, including motivation and improvement of staff performance, identification of competence and skills, identification of educational needs and developmental contexts, etc. Achievement to these objectives is -a responsibility of evaluation system in any organization. The present article examined a sample of 141 full-time instructors of Kermanshah Azad University during the school year of 2010-2011, with the aim of investigating how much these objectives are achieved from instructor's point of view. The instrument used for collecting data included a researcher-made close-ended questionnaire with 25 items in likert scale and an open-ended questionnaire of $88 \%$ validity. To analyze the data, both descriptive and inferential statistics were used. The results indicate that current instructor evaluation system has been successful in noticing student and department managers' opinions about instructor evaluation, instructors' awareness of students' opinion about their performance, determining compatibility of instructors' performance with criteria of professional behavior. But it has no significant place in utilizing colleague's opinions and self-evaluation, improvement of attitudes and educational investigative skill, informing instructors of evaluation results, constructive feedback and using instructors' good research works to evaluate their performance.
\end{abstract}

Keywords Performance Evaluation, Responsibility, Evaluation Methods

\section{Introduction}

In present changing days, having and reaching goals in the organization appropriately is considered a developmental principle and these major goals are performed through a formulated program in the organization. To know the level of acceptance of plans and performance results in complex and dynamic environment. Government and organizations need to design, formulate, and administrate their plans and lack of such a system is a sign of weakness. Hence, it is expected that careful performance in system leads to organizational development and improvement. The main principle in evaluating reasonable performance in organizational is to identify and know the organization and its administration strategies. In order to administrate a rich and dynamic system, organizations should establish an evaluation center. After the establishment of the evaluation center, criteria and principles of performance evaluation should be designed to identify the organization [1]. Performance evaluation as a formal structure consists of a system of measuring, evaluating and effectiveness on individual's features, behaviors and career gains, level of interest, and determining their present performance level. These efforts will lead to identify the level of individual's benefits and possibility of continuing effective, even more effective performance in the future, so that the individual, organization and community could benefit from it [2]. Casio, defining performance evaluation as investigating strength and weakness related to individuals or groups performance of an organization. Abbaspour, [3] defines performance evaluation as the process of identifying, observing, measuring, and improving human performance in organizations.

An evaluation system is a set of performance measurements (that is to qualify performance efficiency and effectiveness) which provides useful information about the organization and it is useful in managing, controlling and modifying organizational activities. Information from performance evaluation must be detailed, scheduled, and useful for those who need it. Furthermore performance evaluation must be designed in a way to reflect major factors in taking benefits, in order for the organization to survive. However, designing such a plan is difficult and needs to consider the point that performance evaluation system is different from one organization to others [4]. To summarize, performance evaluation can be defined as a process by which performance is measured and examined formally at time 
intervals [1: $\mathrm{p} 13]$.

Higher education as the main channel of development in science and ethics in a continuing and dynamic process the final goal of which is to educate a high spirit individual is of special sensitivity, so that this sensitivity in universities is much more observable than other institutions. Nowadays, a common way of evaluating university instructor is to evaluate instructors by student's opinions about them. At the same time, in evaluating instructors, they prefer a multi dimensional method that is a method consisting of several methods [5]. those students who believe they get an " $A$ " tend to have a positive attitude to their instructors, compared with those who believe they get a "C" [6]. At the same time, $\mathrm{Mc}$ Kinach [7] points out that student can not investigate all teaching aspects equally and properly. Based on these findings one can conclude that evaluating instructors with only one instrument and attitude is not appropriate for approaching goals of evaluation and/or promote the basis of satisfactory performance and decision making. This was suggested in related research results and it is apparent that faculty members' concern is students' opinions about them because of their promotion and priority [8], quoted by Gall, [9]. In a study, Fattahi \& et. al. [10] found that most of instructors admitted the principle of evaluation; however, regarding the point that instructors' evaluation is affected by different factors, it's better to employ a multidimensional method with appropriate questions, administration and confidential feedback of results. In order to encourage instructors and validate the results, it's better to promote the instructors annually and select the best one using the results from the evaluations.

Taking related research results into account, it seems that the current methods of evaluating instructors of Azad University of Kermanshah have encountered problems and challenges. This paper, therefore, aims to identify these problems and finds out whether the current program of instructors' performance evaluation has been successful in approaching evaluation goals. The present study can also be helpful in identifying and clarifying instructors' performance evaluation, the result of which can help planners and authorities in making decisions in this area. It also makes them be aware of the fact that they should be careful in evaluating and making good judgments. Thus, the major purpose of this study is to investigate problems and challenges facing the plan of instructors' performance evaluation in Azad University of Kermanshah and its impact on determining their level of competence and performance improvement. To reach this aim, the following questions have been raised in the study:

1. How much has the current instructor evaluation method been successful in using different methods of performance evaluation?

2. How much has the current instructor evaluation method been successful in providing instructors' cooperation to improve evaluation process?

3. How much has the current instructor evaluation method been successful in determining level of competence?

4. How much has the current instructor evaluation method been successful in performance (knowledge, skill, and attitude) improvement?

5. How much has the current instructor evaluation method been successful in reflective constructive feedbacks to them?

\section{Materials and Methods}

\subsection{Methodology}

\subsubsection{Method of the Present Study}

The method of the present study, regarding the purpose is applied and with respect to administration approach is a survey. A survey is a kind of research by which individuals or groups' attitudes, feelings and opinions toward a problem, issue, phenomenon, or entity is identified and clarified [11, 12]. This method was employed in two ways: longitudinal and cross-sectional. In longitudinal method, information was collected during a specific length of time. In cross-sectional method, however, information was collected from a predetermined population in a specific point of time $[11,12]$. Since the information collected from Kermanshah Azad University instructors was also investigated in this research to identify challenges and problems of planning performance evaluation and giving recommendation to improve collecting and analysis phases, the method applies here was a cross-sectional survey.

\subsubsection{Population, Sample Size and Sampling Method}

The population of this study consisted of all full-time instructors working in Kermanshah Azad University in school year of 2010-2011, $(\mathrm{N}=227)$. Since the population size in the present study is determined, sample size was calculated using Morgan formula (1970) that was a 140 -subject sample, but the sample size was assumed to be more than this since some subjects was likely to deny response; hence, the sample size were considered 160 individual. Since the list of population members was available, subjects were determined using a list of instructors through random sampling and random number table, and questionnaires were distributed among them. In this population, 149 subjects accepted our invitation. 8 questionnaires, however, were not completely filled in and were out of the analysis process and only 141 questionnaires were analyzed.

\subsubsection{Instrument of Collecting Data and Its Validity and Reliability}

In the present study, the instrument of collecting data was a research-made close-ended questionnaire with Likert scale to identify problem and challenges with the current performance evaluation plan, and an open-ended question to give better ideas for improving the plan of evaluating the 
instructors. The close-ended questionnaire had 25 questions used to measure the level of success of the current plan for evaluating instructors' performance (knowledge, skill and attitude), reflecting constructive feedback, providing cooperation, and using different methods performance evaluation. In order to provide good ways of improving instructors' evaluation plans, one open-ended question has been used to show their opinions about this issue. Context validity of instrument of collecting data was confirmed by experts after revision and modification, and its reliability was calculated as 0.88 using Cronbache alpha showing its high reliability.

\subsubsection{Analyze the Data}

To analyze the data, descriptive statistics, i.e., frequency, mean and standard deviation was used and to test research questions inferential statistics (Chi-square test) was used.

\subsection{Statistical Analysis}

Table 1. Age and professional history of subject

\begin{tabular}{|c|c|c|c|c|c|c|c|}
\hline Features & Frequency & Mean & Mode & Index & SD & minimum & maximum \\
\hline Age & 141 & 35.36 & 35 & 36 & 5.53 & 26 & 51 \\
\hline $\begin{array}{c}\text { Professional } \\
\text { history }\end{array}$ & 141 & 6.48 & 5 & 3 & 4.60 & 1 & 18 \\
\hline
\end{tabular}

\subsubsection{Demographic characteristics of the sample}

Based on demographic features of samples in table (1), the youngest subject was 26 years old and the oldest one was 51 years old. The average age was about 35 . The average professional history of subjects was about 6 years. The least years of career were 1 and their most one was 18.

Table 2. Evaluation plan success in using different methods

\begin{tabular}{|c|c|c|c|c|c|c|c|}
\hline Raw & Dimensions & $\begin{array}{c}\text { Level of } \\
\text { success }\end{array}$ & $\begin{array}{l}\text { Observed } \\
\text { frequency }\end{array}$ & $\begin{array}{l}\text { Expected } \\
\text { frequency }\end{array}$ & $\begin{array}{l}\text { Degree of } \\
\text { freedom }\end{array}$ & Chi-square & $\begin{array}{c}\text { Significance } \\
\text { level }\end{array}$ \\
\hline \multirow{5}{*}{1} & \multirow{5}{*}{$\begin{array}{l}\text { Using students opinions in } \\
\text { evaluating instructors' } \\
\text { performance }\end{array}$} & Very high & 10 & 28.2 & \multirow{5}{*}{4} & \multirow{5}{*}{75.64} & \multirow{5}{*}{0.0001} \\
\hline & & high & 66 & 28.2 & & & \\
\hline & & average & 34 & 28.2 & & & \\
\hline & & low & 16 & 28.2 & & & \\
\hline & & Very low & 15 & 28.2 & & & \\
\hline \multirow{5}{*}{2} & \multirow{5}{*}{$\begin{array}{l}\text { Using colleagues' opinions in } \\
\text { evaluating instructors }\end{array}$} & Very high & 0 & 35.2 & \multirow{5}{*}{3} & \multirow{5}{*}{1.090} & \multirow{5}{*}{0.0001} \\
\hline & & high & 3 & 35.2 & & & \\
\hline & & average & 8 & 35.2 & & & \\
\hline & & low & 53 & 35.2 & & & \\
\hline & & Very low & 77 & 35.2 & & & \\
\hline \multirow{5}{*}{3} & \multirow{5}{*}{$\begin{array}{l}\text { Using self evaluation in } \\
\text { evaluating instructors }\end{array}$} & Very high & 0 & 35.2 & \multirow{5}{*}{3} & \multirow{5}{*}{1.719} & \multirow{5}{*}{0.0001} \\
\hline & & high & 1 & 35.2 & & & \\
\hline & & average & 3 & 35.2 & & & \\
\hline & & low & 40 & 35.2 & & & \\
\hline & & Very low & 97 & 35.2 & & & \\
\hline \multirow{5}{*}{4} & \multirow{5}{*}{$\begin{array}{l}\text { Using department } \\
\text { administrators' opinions in } \\
\text { evaluating instructors }\end{array}$} & Very high & 0 & 35.2 & \multirow{5}{*}{3} & \multirow{5}{*}{60.504} & \multirow{5}{*}{0.0001} \\
\hline & & high & 2 & 35.2 & & & \\
\hline & & average & 63 & 35.2 & & & \\
\hline & & low & 49 & 35.2 & & & \\
\hline & & Very low & 27 & 35.2 & & & \\
\hline \multirow{5}{*}{5} & \multirow{5}{*}{$\begin{array}{l}\text { The role of instructors' research } \\
\text { works in evaluating them }\end{array}$} & Very high & 3 & 28.2 & \multirow{5}{*}{4} & \multirow{5}{*}{4.057} & \multirow{5}{*}{0.0001} \\
\hline & & high & 4 & 28.2 & & & \\
\hline & & average & 44 & 28.2 & & & \\
\hline & & low & 59 & 28.2 & & & \\
\hline & & Very low & 31 & 28.2 & & & \\
\hline
\end{tabular}




\subsubsection{Using Students in Evaluating Faculty}

According to table (2), the rate of using student's opinion by the present plan for evaluating instructors at levels of very high, high, average, low, very low was $10,66,34$, and 16 , respectively, whereas the frequency was expected to be 28.2 for each of the above levels. Thus, the results of Chi-square show that the level of significance was lower than 0.1 i.e., there is a significant difference between the frequencies. Since the highest frequency of selecting options was of high level, students' opinions are used properly. At the same time, regarding success of current method of instructors' evaluation in using colleagues' opinions, selecting focus on "very low" option and level of significance in this aspect is lower than 0.1 indicating that there is a significant statistic difference between frequencies, as a result with 0.99 possibility one can expect that in current plan, there is a low level of employing colleagues opinion in evaluating instructors' performance. Regarding the aspect of employing self-evaluation, based on different frequencies in the table, and because significance level of chi-square test was lower than 0.1, the research hypothesis is accepted, that there is a significant difference between frequencies, therefore we can be sure that self-evaluation has not position. Also, regarding the point that in investigating differences between frequencies of level of responding to employing the current method of evaluation in department administrators" opinion, level of significance is lower than 0.1 , as a result one can surely say that the current plan of evaluation has been successful in employing department administrators' opinions regarding instructors' evaluation. finally, regarding the impact of studies of instructors in their current evaluation plan, the result of inferential analysis show that chi-square test level of significance was lower than 0.1 and the null hypothesis is admitted, based on which there is a significant different between frequencies. Thus, we can claim that in the current plan of evaluating instructors' efforts and studies by the instructors are not employed properly in evaluating instructor's performance so that a low level of its use has been reported.

Table 3. Evaluation of teachers plan success in providing cooperation

\begin{tabular}{|c|c|c|c|c|c|c|c|}
\hline Raw & Dimensions & $\begin{array}{l}\text { Level of } \\
\text { success }\end{array}$ & $\begin{array}{l}\text { Observed } \\
\text { frequency }\end{array}$ & $\begin{array}{l}\text { Expected } \\
\text { frequency }\end{array}$ & $\begin{array}{c}\text { Degree of } \\
\text { freedom }\end{array}$ & Chi-square & $\begin{array}{c}\text { Significance } \\
\text { level }\end{array}$ \\
\hline \multirow{5}{*}{1} & \multirow{5}{*}{$\begin{array}{l}\text { Providing cooperation to reach goals } \\
\text { of performance evaluation plan }\end{array}$} & Very high & 1 & 28.2 & \multirow{5}{*}{4} & \multirow{5}{*}{1.780} & \multirow{5}{*}{0.0001} \\
\hline & & high & 1 & 28.2 & & & \\
\hline & & average & 6 & 28.2 & & & \\
\hline & & low & 59 & 28.2 & & & \\
\hline & & Very low & 74 & 28.2 & & & \\
\hline \multirow{5}{*}{2} & \multirow{5}{*}{$\begin{array}{l}\text { Promoting and encouraging } \\
\text { cooperation in designing, formulating } \\
\text { and administering instructors' } \\
\text { performance evaluation system }\end{array}$} & Very high & 11 & 28.2 & \multirow{5}{*}{4} & \multirow{5}{*}{28.752} & \multirow{5}{*}{0.0001} \\
\hline & & high & 33 & 28.2 & & & \\
\hline & & average & 36 & 28.2 & & & \\
\hline & & low & 45 & 28.2 & & & \\
\hline & & Very low & 16 & 28.2 & & & \\
\hline \multirow{5}{*}{3} & \multirow{5}{*}{$\begin{array}{l}\text { Promoting and encouraging } \\
\text { cooperation in improving instructors' } \\
\text { performance strengths and modifying } \\
\text { their weaknesses and those of their } \\
\text { colleagues }\end{array}$} & Very high & 0 & 35.2 & \multirow{5}{*}{3} & \multirow{5}{*}{1.654} & \multirow{5}{*}{0.0001} \\
\hline & & High & 1 & 35.2 & & & \\
\hline & & Average & 3 & 35.2 & & & \\
\hline & & Low & 42 & 35.2 & & & \\
\hline & & Very low & 95 & 35.2 & & & \\
\hline
\end{tabular}

\subsubsection{Providing Assistance to Educators, to Develop Goals}

As seen table (3), chi-square test shows the frequencies of questions regarding providing cooperation among instructors in developing goals of evaluation plan at each level in which level of significance is lower than 0.1 , that is to say there is a significant difference between frequencies. Therefore, considering frequencies in the above table, it is possible to conclude than the current evaluation plan, in Kermanshah Azad University instructors" opinion was not been successful in providing cooperation for instructors to develop goals of this plan, encourage instructors in designing, formulating, and administering evaluations system, and improving strength and modifying weakness in themselves and their colleagues. 
Table 4. Evaluation of teachers plan for success in identifying their competence level

\begin{tabular}{|c|c|c|c|c|c|c|c|}
\hline Raw & Dimensions & $\begin{array}{c}\text { Level of } \\
\text { success }\end{array}$ & $\begin{array}{l}\text { Observed } \\
\text { frequency }\end{array}$ & $\begin{array}{l}\text { Expected } \\
\text { frequency }\end{array}$ & $\begin{array}{c}\text { Degree of } \\
\text { freedom }\end{array}$ & Chi-square & $\begin{array}{c}\text { Significance } \\
\text { level }\end{array}$ \\
\hline \multirow{5}{*}{1} & \multirow{5}{*}{$\begin{array}{l}\text { Identifying the level of } \\
\text { consistency of instructors' } \\
\text { performance with } \\
\text { instructional standards }\end{array}$} & Very high & 0 & 35.2 & \multirow{5}{*}{3} & \multirow{5}{*}{1.245} & \multirow{5}{*}{0.0001} \\
\hline & & high & 1 & 35.2 & & & \\
\hline & & average & 5 & 35.2 & & & \\
\hline & & low & 57 & 35.2 & & & \\
\hline & & Very low & 78 & 35.2 & & & \\
\hline \multirow{5}{*}{2} & \multirow{5}{*}{$\begin{array}{l}\text { Identifying the level of } \\
\text { consistency of instructors' } \\
\text { performance with } \\
\text { professional behavior } \\
\text { standards }\end{array}$} & Very high & 7 & 28.2 & \multirow{5}{*}{4} & \multirow{5}{*}{82.227} & \multirow{5}{*}{0.0001} \\
\hline & & high & 20 & 28.2 & & & \\
\hline & & average & 65 & 28.2 & & & \\
\hline & & low & 39 & 28.2 & & & \\
\hline & & Very low & 10 & 28.2 & & & \\
\hline \multirow{5}{*}{3} & \multirow{5}{*}{$\begin{array}{l}\text { Identifying the level of } \\
\text { consistency of instructors' } \\
\text { performance with ethical } \\
\text { standards }\end{array}$} & Very high & 0 & 35.2 & \multirow{5}{*}{3} & \multirow{5}{*}{70.31} & \multirow{5}{*}{0.0001} \\
\hline & & High & 1 & 35.2 & & & \\
\hline & & Average & 70 & 35.2 & & & \\
\hline & & Low & 28 & 35.2 & & & \\
\hline & & Very low & 42 & 35.2 & & & \\
\hline
\end{tabular}

\subsubsection{The Level of Teachers' Performance}

According to table (4), results from chi-square test show that the level of significance is lower than 0.1 and there is a significant difference between frequencies. Therefore we can say that Kermanshah Azad University instructors believe that current plan of evaluation has not worked successfully in identifying level of consistency of instructors 'performance with educational standards.

According to investigations of success of current evaluation plans in identifying the level of consistency of instructors' performance with occupational behavior standards (table 4), the level of significance was lower than 0.1, and therefore there is a significant difference between frequencies. Thus, we can say that to some extent, evaluation plan in Kermanshah Azad University has been successful in identifying the level of consistency of instructors' performance with occupational behavior students and instructors reported this success to be at a moderate level.

Investigation on frequencies of each one of the five levels in identifying the level of consistency of instructors' performance with ethical behaviors in table 4, show that the level of significance of chi-square test is lower than 0.1 , and with a possibility of 0.99 we can say that instructors' performance evaluation plan was to some extent successful in identifying the level of consistency of instructors' performance with ethical behavior.

Table 5. Evaluation of teachers plan for success in improving their performance

\begin{tabular}{|c|c|c|c|c|c|c|c|}
\hline Row & Dimensions & $\begin{array}{c}\text { Level of } \\
\text { success }\end{array}$ & $\begin{array}{l}\text { Observed } \\
\text { frequency }\end{array}$ & $\begin{array}{l}\text { Expected } \\
\text { frequency }\end{array}$ & $\begin{array}{c}\text { Degree of } \\
\text { freedom }\end{array}$ & Chi-square & $\begin{array}{c}\text { Significance } \\
\text { level }\end{array}$ \\
\hline \multirow{5}{*}{1} & \multirow{5}{*}{$\begin{array}{l}\text { Improvement of the level of } \\
\text { knowledge in instruction and } \\
\text { research }\end{array}$} & Very high & 0 & 35.2 & \multirow{5}{*}{3} & \multirow{5}{*}{1.112} & \multirow{5}{*}{0.0001} \\
\hline & & high & 2 & 35.2 & & & \\
\hline & & average & 6 & 35.2 & & & \\
\hline & & low & 65 & 35.2 & & & \\
\hline & & Very low & 68 & 35.2 & & & \\
\hline \multirow{5}{*}{2} & \multirow{5}{*}{$\begin{array}{l}\text { Improvement of the level of } \\
\text { attitude in instruction and } \\
\text { research }\end{array}$} & Very high & 0 & 35.2 & \multirow{5}{*}{2} & \multirow{5}{*}{66.766} & \multirow{5}{*}{0.0001} \\
\hline & & high & 0 & 35.2 & & & \\
\hline & & average & 4 & 35.2 & & & \\
\hline & & low & 55 & 35.2 & & & \\
\hline & & Very low & 82 & 35.2 & & & \\
\hline \multirow{5}{*}{3} & \multirow{5}{*}{$\begin{array}{l}\text { Improvement of the level of } \\
\text { skill in instruction and } \\
\text { research }\end{array}$} & Very high & 0 & 35.2 & \multirow{5}{*}{3} & \multirow{5}{*}{1.225} & \multirow{5}{*}{0.0001} \\
\hline & & High & 1 & 35.2 & & & \\
\hline & & Average & 4 & 35.2 & & & \\
\hline & & Low & 60 & 35.2 & & & \\
\hline & & Very low & 79 & 35.2 & & & \\
\hline
\end{tabular}




\subsubsection{The Success of the Current Evaluation Plan}

According to the results of the table (5) from investigating level of significance among frequencies, level of success of current evaluation plan in improving educational and research knowledge of each instructors of different levels of very high, high, average, low, very low, in chi-square test is lower than 0.1 that is to say that there is a significant difference between frequencies.

Therefore, with possibility of 0.99, Kermanshah Azad University instructors believe that the current plan of evaluation has not worked properly in improving instructors' level of educational and research knowledge. According to chi-square test result in investigation frequencies of all five levels, the success of this plan in improving educational and research attitude and skills of instructors, level of significance was lower than 0.1 indicating the existence of a significant difference between frequencies. Thus we can claim with 0.99 percent confidence that current evaluation plan has not worked properly in evaluating instructors' performance in Azad University of Kermanshah.

Table 6. Evaluation of teachers plan for success in reflecting constructive feedback to them

\begin{tabular}{|c|c|c|c|c|c|c|c|}
\hline Raw & Dimensions & Level of success & $\begin{array}{l}\text { Observed } \\
\text { frequency }\end{array}$ & $\begin{array}{l}\text { Expected } \\
\text { frequency }\end{array}$ & $\begin{array}{c}\text { Degree of } \\
\text { freedom }\end{array}$ & Chi-square & $\begin{array}{c}\text { Significance } \\
\text { level }\end{array}$ \\
\hline \multirow{5}{*}{1} & \multirow{5}{*}{$\begin{array}{l}\text { Informing instructors of } \\
\text { evaluation results and giving } \\
\text { constructive feedback to them }\end{array}$} & Very high & 0 & 47 & \multirow{5}{*}{2} & \multirow{5}{*}{70.596} & \multirow{5}{*}{0.0001} \\
\hline & & high & 0 & 47 & & & \\
\hline & & average & 4 & 47 & & & \\
\hline & & low & 52 & 47 & & & \\
\hline & & Very low & 58 & 47 & & & \\
\hline \multirow{5}{*}{2} & \multirow{5}{*}{$\begin{array}{l}\text { Instructors' awareness of } \\
\text { students' attitudes toward their } \\
\text { performance }\end{array}$} & Very high & 5 & 28.2 & \multirow{5}{*}{4} & \multirow{5}{*}{1.091} & \multirow{5}{*}{0.0001} \\
\hline & & high & 75 & 28.2 & & & \\
\hline & & average & 29 & 28.2 & & & \\
\hline & & low & 21 & 28.2 & & & \\
\hline & & Very low & 11 & 28.2 & & & \\
\hline \multirow{5}{*}{3} & \multirow{5}{*}{$\begin{array}{l}\text { Instructors' awareness of } \\
\text { colleagues' attitudes toward } \\
\text { their performance }\end{array}$} & Very high & 0 & 35.2 & \multirow{5}{*}{3} & \multirow{5}{*}{1.256} & \multirow{5}{*}{0.0001} \\
\hline & & High & 1 & 35.2 & & & \\
\hline & & Average & 3 & 35.2 & & & \\
\hline & & Low & 67 & 35.2 & & & \\
\hline & & Very low & 70 & 35.2 & & & \\
\hline
\end{tabular}

\subsubsection{Reflected in the Survey Results}

Results from chi-square test in table (6) show that in investigating frequencies for level of success of current evaluation plan in reflecting results from evaluations to instructors and giving constructive feedbacks to them at different levels of very high, high, average, low, and very low, was lower than 0.1, i. e., there is a significant difference between frequencies. Since the focus of frequencies is on very low option, with possibility of 0.99 percent we can claim that Kermanshah Azad University instructors believe that the current plan of evaluation has been weak in reflecting evaluation results to instructors and giving constructive feedback to them. Level of significance for each one of the five levels of success of the current evaluation plan in informing instructors of their students' attitudes toward their performance was lower than 0.1 ; therefore, research hypothesis indicating that there is a significant difference between frequencies, is accepted. Thus, with a possibility of 0.99 percent we can say that instructors' performance evaluation plan has been successful in informing instructors of their students' attitudes toward their performance and instructors reported this success to be acceptable. In the aspect of instructors' awareness of their colleagues attitudes toward their performance, level of significance for chi-square test was lower than 0.1; therefore, there is a significant difference between frequencies and with a possibility of 0.99 percent one can say that instructors evaluation plan has not been successful in instructors' awareness of colleagues attitudes toward their performance and most instructors reported this success to be low and very low.

\section{Conclusion}

\subsection{Discussion and Conclusion}


Investigations on using different methods in the current evaluation plan indicates that Kermanshah Azad University instructors believe that in the current plan, students' opinions are taken into account in a proper way, and department administrators' opinion is also considered to some extend in evaluating instructors' performance, their research studies, however, are not taken into account in their performance evaluation. On the contrary the rate of using colleagues' opinion in evaluation is very low. Also, in the aspect of employing self evaluation frequencies indicate that self evaluation has no real place and its use is very low. In a study, Fattahi, et al [10] reported that most instructors believe that their performance is influenced by many factors and it is better to employ multi dimensional evaluation methods, administrate it properly, and give confidential feedbacks to them. With the aim of determining results from instructors' evaluation, Abdul Hussein Shakoornia [13], during a 10-year period, concluded that in evaluating of instructors by students' remains the same, in spite of the fact that the evaluators are different. Adhami et al [14] compared the results of instructor's self-performance with students' opinions, which indicated that instructors gave rather higher scores to themselves than their students and had higher satisfaction with their instruction methods and performance than what their students think. Nasr, Husseini, and Mardani believe that the common way of evaluation all over the world and in Iran is evaluation by students which follows four goals: improving instructions, giving promotion to instructors, selecting subjects by students, and conducting research [15]. As seen, conducted researches aimed to investigate instructors' performance from students' point of view and self evaluation. The results have been consistent with the present study results.

Based on observations one can say that instructors of Kermanshah Azad University believe that with 0.99 possibilities the current evaluation plan has been weak in providing cooperation for instructors to reach the goal of evaluating instructors' performance. In summary we can say that the evaluation plan employed in Kermanshah Azad University has been so weak in reaching goals of evaluation, instructors' cooperation in designing and formulating an administration and evaluation system, promotion an encouraging cooperation in instructors to improve their strengths and modify their weaknesses as well as those of their colleagues.

Mehri Ghafourian Boroojerdnia, Abdul Hussein Shakoornia, and Hussein Elhampour [16], conducted a research with the aim of investigating instructors' opinions regarding the impact of feedback on improving instruction methods in a descriptive-cross sectional method in which all non-clinical instructors in Ahvaz medical university (130 individuals) were studied. The results of this study showed that although 55.1 percent of instructors agree with the current evaluation system 55.5 percent of them agree with reporting the evaluation scores to department administrators and 49.5 percent believe that one effective way to promote instruction quality is to report evaluation scores to the faculty administrators. Comparing investigations of results from self evaluation of medical university faculties in Mazandaran with evaluation of students, by Kurosh Vahid Shahi and Hamid Mohamad Jafari [16], showed that in the current method of instructors' evaluation by students, 95 percent of students and 80.6 percent of instructor's prefered the current method but there was a significant difference between scores of instructor's self evaluation and evaluation by students.

The summary of research results show that although evaluation details have not been considered in other studies and there is no research investigating directly the variables of the present research, it seems that most instructors prefer the method of reporting scores of evaluation as a proper feedback in improving instruction quality but they believe that using different methods of evaluation is not a good way. Here the results are consistent with the present study.

Results from investigating the level of success of current plan of evaluating instructors' performance in identifying the level of consistency of instructors' performance with instructional standards show that Kermanshah Azad University instructors believe that with 0.99 percent confidence, the current plan has been very weak in identifying the level of consistency of instructors' performance with instructional standards, but it has been, to some extent, successful in identifying instructor's performance with professional ethical standards and instructors reported this success to be at an average level. Results from other studies also show that the plan of evaluating instructors' performance has been, to some extent, successful in identifying the level of consistency of instructors' performance with ethical standards. In this aspect, there is no record to be compared with available results.

According to results from investigations on the impact of the current performance (knowledge, skill, and attitude) evaluation system, Kermanshah Azad University instructors reported that the success of this plan was very low or low in improving performance in knowledge, attitude, skills in instruction and research. However, it is expected that evaluation as a method of identifying problems and helping the development of instructors' knowledge and scientific skill will be employed. In different studies this has been claimed. Milanowski (2004) for example, conducted a study on the analysis of the relationship between scores of evaluating teachers' performance and students' marks in reading, mathematics and science in western schools of the $U$. S. A., the results of which confirmed this relationship. Odhiambo [17] in one section of his research concluded that evaluation encourages effective instruction which leads to better quality of instruction. Comparison of results from this research with other researches, show that evaluation must be effective on students' knowledge, skill, and attitude, however, results from the present study show that evaluation method used in Kermanshah Azad University is not successful in this regard.

Investigation on related data to reflect feedback of performance evaluation to instructors shows that instructors of Kermanshah Azad University believed that the current 
plan has been very weak in reflecting results giving feedback to instructors. Also, regarding instructors' awareness of colleagues' attitudes toward their performance has not been so successful and most of instructors say that its success is very low or low. However, it was successful in instructors' awareness of students' attitudes toward their performance and instructors reported it to be acceptable. Odhiambo [17], also concluded that giving feedback is important in improving teachers' performance in classroom and acceptable results are important in improving performance. But, it is can be seen, in spite of the fact that giving feedback is constructive, this has not been done carefully and properly.

\subsection{Applicable Recommendations}

\subsubsection{Get Feedback from Colleagues}

Results of the investigation show that instructors receive no feedback from their colleagues regarding their instructional efforts. So, it is recommended that parts of evaluation investigate instructors' performance from colleagues' point of view to give a better evaluation.

More reviews in the field, indicated that the evaluation process will not be fully implemented and despite the importance of feedback and its impact on improving the training, evaluation feedback did not care. So, the evaluation process should be reviewed again and be included in the evaluation process, the tool provides feedback.

\subsubsection{Reflection of the Performance Evaluation}

Investigations on instructors' performance evaluation show that efforts and researches by them are not properly reflected in their performance evaluation and its use is low. On this basis, it is recommended that giving scores to instructors' researches and efforts means to consider these works in their evaluation. So, the evaluation will be more real and instructors' motivation to produce knowledge and science is promoted.

\subsubsection{Using Questionnaire in Decision-Making}

Questionnaires on specific subjects are merely important for the purpose of feedback and modifying and optimizing instruction. But they cannot be used in making professional and career decisions. If students' opinions about instructor's performance are used for making decisions, comprehensive questionnaires with more general and extended questions must be provided and administered. These questionnaires must be provided in a way to be applicable for all subjects.

\subsubsection{Assessment Effect in the Knowledge}

Since the evaluation must be effective for knowledge, skills, and attitudes of the subjects, the results of the present study show that the current method of evaluation in Kermanshah Azad University has not been successful in this regard. Therefore it is recommended that the present form be revised.

\subsubsection{Feedback}

Summarizing data show that although in other studies evaluation details are not emphasized, it seems that most instructors believe that reflecting evaluation scores as an appropriate feedback and it is useful to improve instructions, quality. But in using different methods they believe that the evaluation is weak and these results match with that of the present study so we need better planning in this regards.

From the perspective of faculty members, the whole evaluation process was weak. So it is better that the Process to be reconsidered generally. It can be reviewed and reformed, based on the viewpoint of faculty, until this process is complete based on their opinions.

\section{REFERENCES}

[1] M. Hosseini Lorgany, Comparison of learning style bachelor and Master of Science degree in weak and strong men and women, medical and engineering universities. MSc. thesis. Allameh Tabatabai University, Iran, 1998.

[2] M. Tajari, Performance Assessment Organization. Journal of Educational Evaluation, Iran, No. 10. P: 13, 2004.

[3] R. S. Schuler, Sh. L. Dylan, "Personnel and Human Resources Management", translated by M.A. toosi, M. Saedi, Tehran: Center for Public Management, 2002, p290.

[4] a. Abbaspour, Advanced human resource management. Tehran, Samt, 2003, p 214.

[5] S. Tangen. "Analyzing the Requirement of performance Measurement System» Measuring Business Excellence, Bradford, 2005, Vol.9 Issue.4, pp: 46-55.

[6] K.M. Skeff, G.A. Stratos, M.R. Bergen, D.P. Regula. A pilot study of faculty development for basic science teacher. Acad Med 1998; 73(6):701-704.

[7] A. G. Greenwald, G. M.Gillmore, Grading leniency is a removable contaminant of student ratings. American Psychologist, 1997, 52(11): 1209-1217.

[8] W. J. McKeachie, Student rating of faculty: A reprise. Academe, 1979, 65, 384-397.

[9] J. J. Ryan, J. A. Anderson, A. B. Birchler, Student evaluations: The faculty responds. Resean Higher Education, 1980, 12(4), 317-333: 85

[10] A. R Gall, Faculty Perception in the Effects of Student valuations of Teaching on Higher Education Instructional Practices and Instructor Moral. Dissertation submitted to the Graduate College of Marshall University, 2004.

[11] Z. Fattahi, et al, Opinions about the evaluation of the medical faculty at the 82-2002 school year. Hormozgan Medical Journal, Vol. IX, No. I, pp. 66-59.

[12] A. Delaware, Research Methods in Psychology and Education. Tehran: Publication Verayesh, 2008.

[13] M.D. Mertens, Research and evaluation in education and psychology. Sage Publications: Thousand Oask, London, New Delhi, 2004. 
[14] M. Shakurnia, A.H. Ghafourian Boroujerdnia, H. Alhampur, Effects of feedback of evaluation results to improve teaching and non-clinical staff, Ahwaz University of Medical Sciences, 2005

[15] A. Adhami, H. reihani, Z. Fattahi, and others, Evaluation of Kerman (Iran) medical faculty from their perspective and students, and Pace of development in medical education, Journal of Medical Education Development Center, 2005. 2 (1): $32-25$.

[16] AR. Nasr Esfahani, M. Sharif, H. Areezi, "Teaching
Evaluation" Encyclopedia of Higher Education, Ministry of Science, Research and Technology: The Great Encyclopedia Foundation sentences, 2004.

[17] K.M. Vahidshahi, H. Jafari, A comparative study of "self-evaluation" of faculty members of Mazandaran University of Medical Sciences with the evaluation of students, 2005.

[18] G.O. Odhiambo, Teacher Appraisal: The Experiences of Kenyan Secondary School Teacher. Journal of Educational Administration, 2005 .Vol.43.No.4.pp:402-416. 